\title{
GAMBARAN PEMBENTUKAN KADER DAN PELAKSANAAN POSYANDU REMAJA DALAM UPAYA PENINGKATAN KESEHATAN REPRODUKSI REMAJA
}

\author{
Meda Yuliani), Yufina'), Mamay Maesaroh'1) \\ 1)Program Studi D3 Kebidanan, Fakultas IImu Kesehatan, Universitas Bhakti Kencana, Bandung, Indonesia \\ Corresponding author : Meda Yuliani \\ E-mail : meda.yuliani@bku.ac.id
}

Diterima 18 Februari 2021, Direvisi 06 Maret 2021, Disetujui 08 Maret 2021

\begin{abstract}
ABSTRAK
Posyandu remaja merupakan salah satu bentuk Upaya Kesehatan Bersumber Daya Masyarakat (UKBM) yang dikelola dan diselenggarakan dari, oleh, untuk dan bersama masyarakat termasuk remaja dalam penyelenggaraan pembangunan kesehatan untuk meningkatkan derajat kesehatan dan keterampilan hidup sehat remaja. Pembentukan Posyandu Remaja dan kader kesehatan remaja bertujuan untuk meningkatkan kesehatan reproduksi remaja dan sebagai wadah untuk memfasilitasi kebutuhan kesehatan remaja. Berdasarkan survey mawas diri yang dilakukan sebelumnya, terdapat beberapa remaja yang tidak mengetahui tentang kesehatan reproduksi seperti tentang menstruai, resiko perilaku seks tidak bertanggung jawab, serta menurut petugas kesehatan setempat kegiatan posyandu remaja belum terlaksana dengan optimal. Oleh karena itu maka dibentuklah Posyandu remaja dan para kader Remaja di Dusun 2 Cibangkonol Desa Cibiru Wetan Kabupaten Bandung. Dalam penyelanggaraanya, pengelola Posyandu Remaja dipilih melalui proses musyawarah. Dari hasil pembentukan posyandu remaja tersebut didapatkan pengelola posyandu dusun 2, yaitu kader remaja berjumlah 7 orang yang nantinya menjadi perpanjangan tugas dibawah pengawasan Puskesmas Cibiru Hilir. Berdasarkan hasil kesepakatan pelaksanaan posyandu dilaksanakan setiap minggu ke-3. Kegiatan tersebut diawali dengan pemeberian penyuluhan mengenai posyandu remaja, serta pada saat kegiatan awal posyandu remaja diberikan materi-materi penyuluhan tentang kesehatan reproduksi remaja . Diharapkan dengan Pembentukan Posyandu Remaja ini dapat meningkatkan derajat kesehatan remaja serta meningkatkan pengetahuan kesehatan reproduksi bagi para remaja.
\end{abstract}

Kata kunci: kader remaja; kesehatan reproduksi remaja; posyandu remaja

\begin{abstract}
Youth Integrated Healtcare center is a form of Community-Based Health Efforts (UKBM) which is managed and organized from, by, for and with the community, including youth in the implementation of health development to improve the health status and healthy life skills of adolescents. The establishment of Youth Integrated Healtcare center and youth health cadres aims to improve adolescent reproductive health and as a forum to facilitate adolescent health needs. Based on an introspective survey conducted previously, there were a number of adolescents who did not know about reproductive health, such as menstruation, the risk of irresponsible sexual behavior, and according to local health officials, youth Integrated Healtcare center activities had not been implemented optimally. Therefore, youth Integrated Healtcare center and youth cadres were formed in Dusun 2 Cibangkonol, Cibiru Wetan Village, Bandung Regency. In its implementation, the management of the Youth Integrated Healtcare center is selected through a deliberation process. From the results of the formation of the youth Integrated Healtcare center, it was found that the hamlet 2 posyandu manager, namely 7 youth cadres who later became an extension of their duties under the supervision of the Cibiru Hilir Puskesmas. Based on the agreement, the Integrated Healtcare center will be implemented every 3rd week. The activity began with the provision of counseling on youth Integrated Healtcare center, and during the initial activity, youth Integrated Healtcare center was given counseling materials on adolescent reproductive health. It is hoped that the establishment of this Youth Integrated Healtcare center can improve the health status of adolescents and increase knowledge of reproductive health for adolescents.
\end{abstract}

Keywords: youth cadres; adolescent reproductive health; youth integrated healthcare center

\section{PENDAHULUAN}

Pada masa remaja diketahui terjadi perubahan fisik dan seksual. Perubahan fisik yang pesat dan perubahan hormonal merupakan pemicu timbulnya dorongan motivasi seksual yang menjadikan remaja 
rawan terhadap penyakit dan masalah kesehatan reproduksi, kehamilan remaja dengan segala konsekuensinya yaitu hubungan seks pranikah, aborsi, Penyakit Menular Seksual (PMS), HIV-AIDS serta narkotika (Margaretha, 2012).

Masa remaja merupakan masa storm and stress, karena remaja mengalami banyak tantangan baik dari diri mereka sendiri (biopsychosocial factors) ataupun lingkungan (environmental factors).Berdasarkan hasil Survei Kesehatan Berbasis Sekolah di Indonesia tahun 2015 (GSHS) dapat terlihat gambaran faktor risiko kesehatan pada pelajar usia 12-18 tahun (SMP dan SMA) secara nasional, sebanyak $41,8 \%$ laki-laki dan $4,1 \%$ perempuan mengaku pernah merokok, $14,4 \%$ laki- laki dan $5,6 \%$ perempuan pernah mengkonsumsi alkohol, lalu juga didapatkan 2,6\% laki-laki pernah mengkonsumsi narkoba dan perilaku seksual di mana didapatkan $8,26 \%$ pelajar laki-laki dan $4,17 \%$ pelajar perempuan usia 12-18 tahun pernah melakukan hubungan seksual (Puslitbang Kemenkes RI, 2015)

Masalah lain yang teridentifikasi adalah masalah kesehatan reproduksi dan perilaku berisiko pada remaja. Berdasarkan data Global School Heatlh Survey 2015 terdapat 3,3\% remaja anak usia 15-19 tahun mengidap AIDS; hanya $9,9 \%$ perempuan dan $10,6 \%$ laki-laki usia 15-19 tahun memiliki pengetahuan komprehensif mengenai HIV AIDS; dan sebanyak 0,7\% remaja perempuan dan $4,5 \%$ remaja laki-laki pernah melakukan hubungan seksual pranikah (Kemenkes RI, 2019)

Kemajuan teknologi di dunia sangat begitu pesat termasuk di Indonesia, dengan perkembangan teknologi yang pesat maka berkembang juga permasalahan remaja di Indonesia. Ada yang menjurus ke hal positif dan juga ke hal yang negatif di berbagai kota besar di Indonesia, sekitar 20 hingga 30 persen remaja mengaku pernah melakukan hubungan seks. Banyak remaja yang melakukan gaya hidup tidak sehat seperti perilaku seksual sebelum menikah, merokok, menggunakan narkoba, makan- makanan yang tidak sehat dan cara diet yang salah demi menjaga berat badan yang ideal (Sari, 2019)

Melihat kenyataan ini maka pada kelompok remaja, perlu dilakukan pemberian pengetahuan tentang kesehatan reproduksi dan seksual secara komprehensif. Pemberian konseling, informasi dan edukasi (KIE) kesehatan reproduksi diharapkan dapat mempersiapkandiri menjalani masa pubernya sesuai dengan kebutuhannya. Posyandu Remaja atau Pos Pelayanan Terpadu Remaja adalah sebuah wadah Pos Kesehatan Remaja yang memfasilitasi dalam memahami seluk beluk remaja selama masa puber yang ditujukan kepada siswa dan remaja pada umumnya. Selain itu pos pelayanan terpadu remaja berfungsi juga sebagai sebuah wadah untuk memberi remaja kesempatan berkembang sesuai dengan kebutuhan dan karakteristiknya melalui pendekatan terpadu dari segi medis dan agamis (Kemenkes RI, 2018).

Kompleksnya

permasalahan kesehatan pada remaja, tentunya memerlukan penanganan yang komprehensif dan terintegrasi yang melibatkan semua unsur dari lintas program dan sektor terkait, itu diakibatkan karena tidak ada wadah remaja untuk medapatkan pengetahuan dan informasi terkait kesehatan (Sulastri et al., 2019).

Posyandu remaja merupakan salah satu bentuk Upaya Kesehatan Bersumber Daya Masyarakat (UKBM) yang dikelola dan diselenggarakan dari, oleh, untuk dan bersama masyarakat termasuk remaja dalam penyelenggaraan pembangunan kesehatan, guna memberdayakan masyarakat dan memberikan kemudahan dalam memperoleh pelayanan kesehatan bagi remaja untuk meningkatkan derajat kesehatan dan keterampilan hidup sehat remaja.

Pelayanan kesehatan remaja di Posyandu adalah pelayanan kesehatan yang peduli remaja, mencakup upaya promotif dan preventif, meliputi: Keterampilan Hidup Sehat (PKHS), kesehatan reproduksi remaja, kesehatan jiwa dan pencegahan penyalahgunaan Napza, gizi, aktifitas fisik, pencegahan Penyakit Tidak Menular (PTM) dan pencegahan kekerasan pada remaja. Pembentukan posyandu remaja yang dapat digunakan sebagai wadah para remaja untuk menciptakan wadah pembinaan dan memahami pentingnya gaya hidup sehat, meningkatkan pengetahuan remaja tentang kesehatan reproduksi, gizi, mengurangi kejadian kenakalan pada remaja. Pentingnya pemberdayaan kesehatankepada masyarakat dalam hal ini terutama kader remaja merupakan salah satu bentuk strategi promosi kesehatan.

Pelatihan yang diberikan kepada kader remaja merupakan salah satu bentuk upaya meningkatkan pengetahuan remaja terkait kesehatan reproduksi nya. Media yang digunakan dalam pelatihan remaja salah satunya menggunakan modul. Modul merupakan bahan ajar cetak yang dapat digunakan sebagai perantara atau memfasiltasi kegiatan untuk mencapai suatu tujuan pemeberian penyuluhan secara mandiri tanpa bergantung dengan tenaga Kesehatan (Wahyuntari \& Ismarwati, 2020). 
Desa Cibiru Wetan merupakan salah satu desa yang berada di wilayah kerja Puskesmas Cibiru Hilir Kabupaten Bandung. Desa ini terdiri dari beberapa Dusun, salah satunya adalah Dusun 2 Desa Cibiru Wetan. Hasil pendataan didapatkan penikahan dini, usia sekolah yang sudah bekerja, kegaitan remaja tidak ada, permasalahan anemia remaja serta tidak mengetahuinya kesehatan reproduksi khususnya kesehatan reproduksi remaja. Kemudian ditambah kondisi posyandu bagi remaja yang belum terlaksana serta kader remaja sebagai penggeraknyapun belum terbentuk.

Tujuan dilakukannya pengabdian masyarakat ini dengan dibentuknya kader remaja dan posyandu remaja adalah untuk meningkatkan kesehatan reproduksi remaja serta sebagai bentuk upaya pemberdayaan remaja sebagai luaran hasil Iptek Bagi Masyarakat (lbm).

\section{METODE}

Pelaksanaan kegiatan pembentukan dan pelaksanaan Posyandu Remaja ini melibatkan Petugas Kesehatan Puskesmas Cibiru Hilir dan Tokoh Masyarakat Dusun 2 Cibangkonol serta remaja Dusun 2 Cibangkonol sebagai mitra pengabdian.

Pada pelaksanaan kegiatan pengabdian masyarakat ini, dimulai dengan tahapan seperti yang ditunjukkkan pada gambar dibawah ini;

persiapan
- berkoordinasi
dengan tim
-koordinasi
dengan pihak
puskesmas,
aparat setempat
- mempersiapkan
bahan untuk
penyuluhan,
pembentukan
kader dan
posyandu

\begin{tabular}{|l|}
\hline \multicolumn{1}{|c|}{ sosialisasi } \\
\hline -tahap sosialisasi \\
ini dimulai \\
dengan \\
melakukan \\
penyuluhan \\
tentang kegiatan \\
posyandu \\
remaja, kader \\
remaja \\
- pembentukan \\
kader \\
\hline
\end{tabular}

\begin{tabular}{l} 
pelaksanaan \\
- pengesahan \\
pembentukan \\
kader \\
- penyuluhan \\
kesehatan \\
Reproduksi \\
- pemberian \\
pelatihan kader \\
- pelaksanaan \\
posyandu remaja \\
\hline
\end{tabular}

\section{Gambar 1. Tahap Kegiatan}

Metode yang dilakukan pada
pelaksanaan kegiatan pengabdian masyarakat
ini pada umumnya untuk mencari solusi
permasalahan yaitu dengan pembentukan
kader dan posyandu remaja serta peningkatan
pengetahuan remaja mengenai kesehatan
reproduksi remaja melalui penyuluhan tentang
kesehatan reproduksi, tentang seks pranikah
dan tentang penyakit menular seksual.
Kegiatan sosialisasi ini merupakan
salah satu kegiatan awalan dari kegiatan
posyandu remaja. Dalam sosialisasi ini

diperkenalkan dahulu tentang kegiatan posyandu remaja serta tugas kader remaja.

$$
\text { Pelaksanaan Posyandu Remaja }
$$

dimulai dari pengisian KMS dan pengukuran kondisi Remaja, kemudian selanjutnya dilakukan Penyuluhan sebagai upaya dalam peningkatan pengetahuan remaja. Sebelum dilakukan penyuluhan, dilakukan pembagian kuesioner untuk dilakukan pre test dan setelah dilakukan penyuluhanpun diberikan kembali post test sebagai bentuk evaluasi tingkat pengetahuan remaja.

\section{HASIL DAN PEMBAHASAN}

\section{Penyuluhan Kesehatan Reproduksi}

Sebelum dilakukan penyuluhan dilakukan pre test mengenai ruang lingkup kesehatan reproduksi remaja dan tentang posyandu remaja.

Pada Gambar 2 menunjukan kegiatan penyuluhan yang dilakukan ini selain dengan metode ceramah, juga menggunakan media penyuluhan berupa leafleat dan juga media eleteronik melalui penayangan dengan menggunakan LCD sebagai alat bantu penyuluhan.

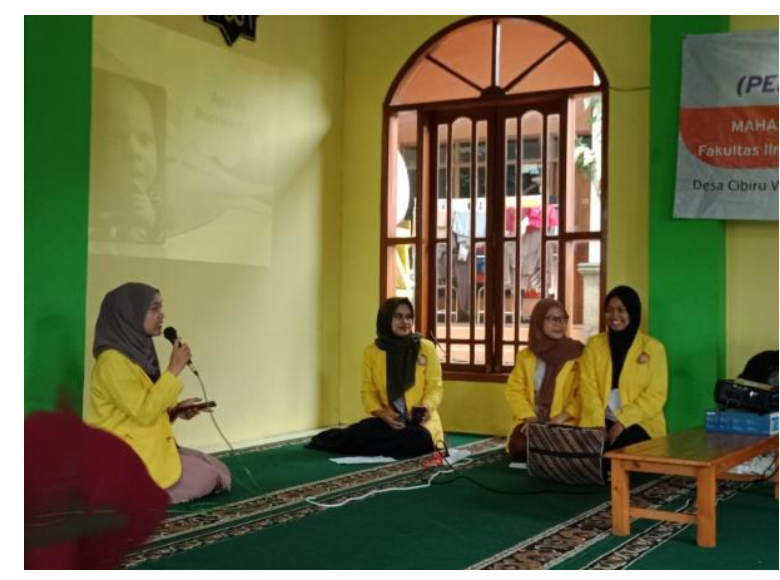

Gambar 2. Penyuluhan Kesehatan Reproduksi Remaja Oleh Tim

Peningkatan pengetahuan remaja salah satunya didukung oleh penggunaan media leaflet. Isi leaflet sesuai dengan materi penyuluhan yang disampaikan dengan gambar dan warna serta menyajikan seluruh poin-poin materi pada leaflet di dalam kuesioner. Leaflet sangat efektif dalam meningkatkan efektifitas penyuluhan dengan metode ceramah, karena leaflet selain merangkum dari keseluruhan materi penyuluhan, juga menyajikan gambar menarik yang memudahkan seseorang memahami isi materi (Saleh \& Kunoli, 2018).

Materi penyuluhan tentang kesehatan reproduksi, seks pra nikah dan penyakit menular seksual. Penyuluhan ini dilakukan pada saat pelaksanaan posyandu remaja. 
Sebelum dilakukan penyuluhan, dilakukan pembagian kuesioner untuk dilakukan pre test dan setelah dilakukan penyuluhanpun diberikan kembali post test. Dari hasil pengisian kuesioner tersebut sebelum dilakukan penyuluhan, pengetahuan remaja tentang penyakit menular seksual, tentang kesehatan reproduksi terutama tentang dismenorhea pada remaja wanita kurang dan setelah dilakukan penyuluhan pengetahuan remaja mengenai hal tersebut terdapat peningkatan.

$$
\text { Penyuluhan kesehatan yang }
$$

dilaksanakan sudah mampu memberdayakan remaja karena memberikan pengetahuan tentang kesehatan yang dibutuhkan remaja agar dapat hidup lebih sehat dan bersih serta mencegah kemungkinan buruk pada usia remaja (Nawangsari, 2017).

Hasil penelitian yang dilakukaan dipadapatkan hasil tes pengetahuan menunjukkan perbedaan pengetahuan ratarata sebelum dan sesudah menggunakan Grup Buzz 3.133. Kesimpulannya adalah level Pencapaian target yang baik, dan remaja merasakan banyaknya manfaat yang diterima semakin meningkat pengetahuan dan keterampilan memberikan KIE kepada rekanrekan mereka (Ruwayda \& Izhar, 2020). Peningkatan pengetahuan dan ketrampilan kader remaja dalam pengelolaan masalah kesehatan remaja dapat meningkatkan kualitas kesehatan remaja (Katan et al., 2014)

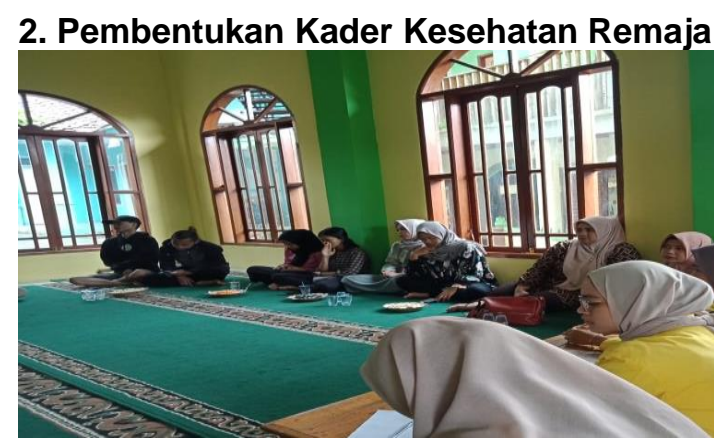

Gambar 3. Suasana Pembentukan Kader

Dalam pelaksanaan posyandu remaja diperlukan kader yang berasal dari kalangan remaja. Pada kegiatan pengabdian masyarakat ini salah satu pemecahan masalahnya yaitu pembentukan kader. Pemilihan dan pembentukan kader kesehatan remaja ini melalui musyawarah pembentukan posyandu remaja, yang diawali dengan pembentukan kader. Seperti terlihat pada gambar 3 dan 4 merupakan situasi pembentukan remaja yang dihadiri oleh para remaja di dusun 2 Cibangkonol. Sebelumnya para remaja yang direkomendasikan oleh para ibu kader setempat dari tiap RW nya di undang dalam tahapan sosialisasi. Dari 15 remaja yang hadir, terpilih 7 remaja dan ditetapkan sebagai kader remaja. Pengurus Posyandu Remaja sekurangkurangnya terdiri dari ketua, sekretaris dan bendahara. Berikut beberapa kriteria pengelola Posyandu Remaja:

a. Sukarelawan

b. Memiliki semangat pengabdian, berinisiatif tinggi dan mampu memotivasi remaja lain.

c. Bersedia bekerja secara sukarela bersama kadar remaja lainnya.

Setalah dibentuknya pengelola posyandu atau dalam hal ini adalah kader lesehtan posyandu yang disahkan dan ditetapkan atas pesetujuan kepala Dusun, Kepala Desa dan oleh Puskesmas, para kader kesehatan remaja ini diberikan informasi dan pelatihan mengenai kegiatan posyandu, melakukan pelayanan berupa pengukuran tekanan darah, pengisian format dari KMS remaja dan pencatatan.

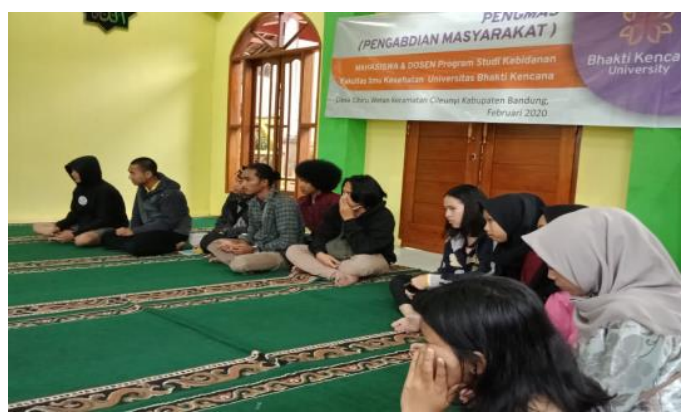

Gambar 4. Breefing Persiapan Pelaksanaan Posyandu Remaja Kepada Para Kader

Permasalahan yang ada pada remaja khususnya anak sekolah usia SMP dan SMA ataupun sederajat sangatlah komplek maka sangat perlu adanya program untuk melakukan pencegahan maupun penanggulangan secara dini yang melibatkan pihak sekolah dan kesehatan serta masayarakat. Sehubungan dengan hal tersebut maka diperlukan suatu program yang mendukung tingkat perkembangan masa remaja salah satunya dengan pembentukan kader kesehatan remaja yang melibatkan sekolah dan masyarakat. Kader Kesehatan Remaja adalah peserta didik yang dipilih untuk mengikuti dan melaksanakan sebagian usaha pelayanan kesehatan terhadap diri sendiri, keluarga, teman peserta didik pada khususnya dan sekolah pada umumnya. Remaja yang memiliki masalah kesehatan maupun masalah yang lain diharapkan dapat mendapatkan pertolongan dari teman yang menjadi kader kesehatan remaja (Izah et al., 2019). 


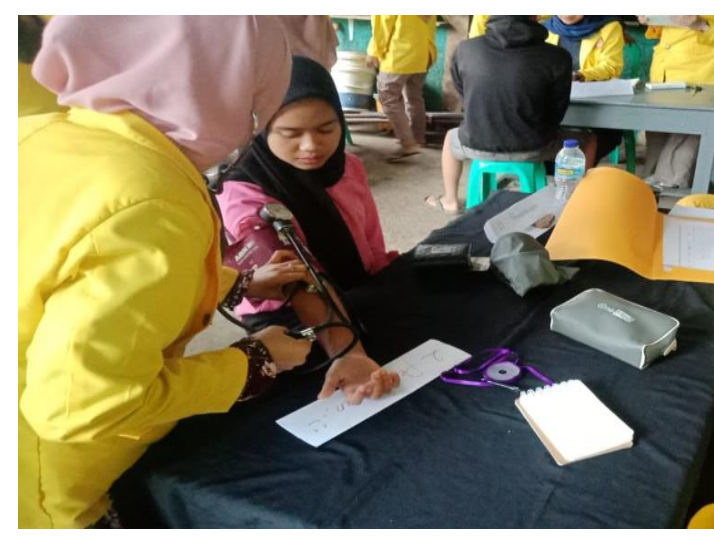

Gambar 5. Pemberian Pelatihan Kader Dalam persiapan Pelaksanaan Posyandu Remaja

Setelah terbentuknya kader remaja, untuk mendukung program posyandu remaja tersebut, para remaja yang terpilih menjadi kader tersebut diberikan pelatihan cara mengukur tekanan darah, melakukan pendokumentasian, dll nya.

Adanya panutan seperti kader remaja dan konselor sebaya yang tinggal di lingkungan yang sama dengan remaja yang mengikuti posyandu remaja membuat para remaja merasa ada yang terus mengingatkan dan memperbaiki segala tindakan yang menjurus kepada perilaku seksual yang berisiko sehingga membuat perbedaan praktik pada kelompok remaja yang tidak mengikuti posyandu. (Afrita et al., 2019).

Pendapat dan pandangan teman biasanya lebih diterima daripada pendapat orang tua. Informasi mengenai kesehatan reproduksi dan bimbingan seksual yang diperoleh melalui teman sebaya (peer) sedikit banyak telah memberikan dorongan untuk menentukan sikap seorang remaja dalam melakukan interaksi dengan pasangannya (Zimmer-Gembeck, 2002).

Terbentuknya kader remaja ini bisa menghadirkan media atupun perantara dalam peningtkan pengentahuan bagi para remaja. Seperti juga yang dilakukan oleh esti pada tahun 2019, terbentuknya kader kesehatan remaja IPNU IPPNU di Desa Buniwah Kecamatan Sirampog Kabupaten Brebes yang mampu memberikan informasi kesehatan kepada teman sebaya khususnya tentang HIV dan AIDS sehingga akan meningkatkan pengetahuan remaja (Janah et al., 2019).

\section{Pelaksanaan Posyandu Remaja Kegiatan Posyandu Remaja}

1.Tahap Persiapan

Tahap persiapan sudah berjalan beberapa hari sebelum hari pelaksanaan posyandu remaja dan telah disepakati dan di diskusikan pada saat Musyawah Dusun. Pada hari $\mathrm{H}-1$ kader dan pengelola mengecek kesiapan dan kelengkapan posyandu.

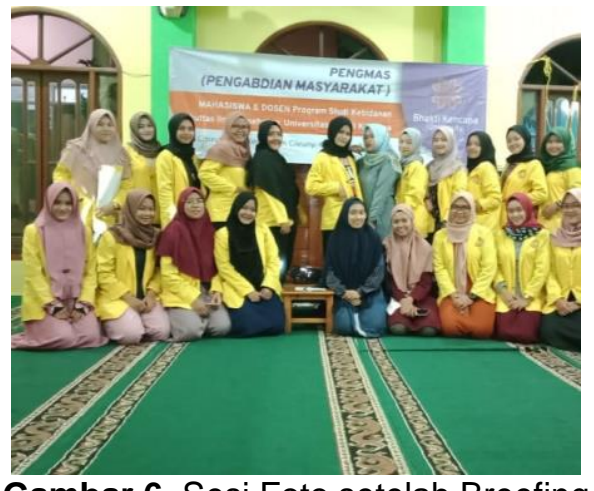

Gambar 6. Sesi Foto setelah Breefing Persiapan Pembentukan Kader dan Pelaksanaan Posyandu Remaja

\section{Tahap Pelaksanaan}

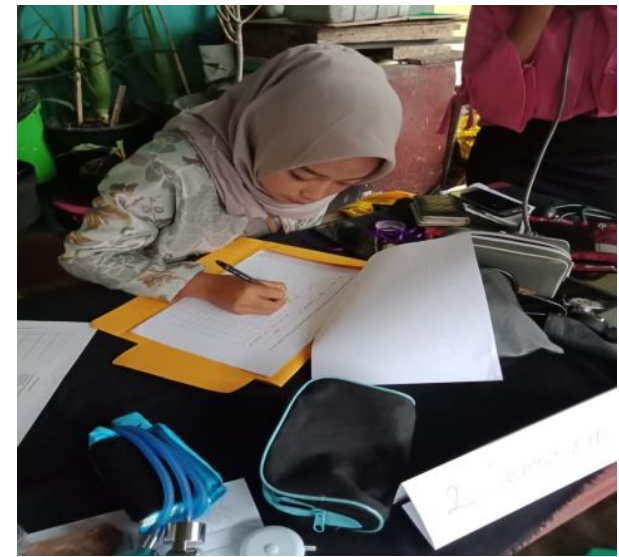

Gambar 7. Kader Remaja Sedang Melakukan pengisisan pencatatan

Dalam Tahapan Pelaksanaan Posyandu Remaja. Dimulai dengan pengisian daftar hadir, pengukuran berat badan, tinggi badan dan pengukuran tekanan darah. Seperti terlihat pada gambar 7 terlihat kader remaja melakukan pencatatan hasil pemriksaan.

Langkah-langkah yang dilaksanakan pada posyandu remaja adalah seperti yang terlihat pada Tabel 2 berikut:

Tabel 1. Tahapan Pelaksanaan Posyandu

\begin{tabular}{ccl}
\hline Langkah & Kegiatan & Pelaksana \\
\hline & Pendaftaran & \\
& 1. Pengisian & \\
& daftar hadir & \\
& 2. Untuk & Kader \\
Pertama & kunjungan & dibantu \\
& pertama & oleh tim \\
& kali,remaja & \\
& mengisi & \\
& formulir data & \\
& diri dan & \\
\hline
\end{tabular}




\begin{tabular}{|c|c|c|}
\hline & $\begin{array}{l}\text { pengisian } \\
\text { form atau } \\
\text { kuesioner }\end{array}$ & \\
\hline Kedua & $\begin{array}{l}\text { Pengukuran } \\
\text { 1. Penimbangan } \\
\text { Berat Badan } \\
\text { (BB) } \\
\text { 2. Pengukuran } \\
\text { Tinggi Badan } \\
\text { (TB) } \\
\text { 3. Pengukuran } \\
\text { Tekanan } \\
\text { darah (TD) } \\
\text { dan } \\
\text { 4ingkar } \\
\text { Lengan Atas } \\
\text { (LILA) dan } \\
\text { Lingkar Perut } \\
\text { Pengecekan } \\
\text { anemia untuk } \\
\text { remaja putri } \\
\text { secara klinis, } \\
\text { apabila ada } \\
\text { tanda klinis } \\
\text { anemia } \\
\text { dirujuk ke } \\
\text { fasilitas } \\
\text { kesehatan }\end{array}$ & $\begin{array}{l}\text { Kader } \\
\text { dibantu } \\
\text { oleh tim }\end{array}$ \\
\hline Ketiga & $\begin{array}{l}\text { Pencatatan } \\
\text { Kader } \\
\text { melakukan } \\
\text { pencatatan } \\
\text { hasil } \\
\text { pengukuran ke } \\
\text { dalam buku } \\
\text { register dan } \\
\text { Buku } \\
\text { Pemantauan } \\
\text { Kesehatan } \\
\text { Remaja }\end{array}$ & $\begin{array}{l}\text { Kader } \\
\text { dibantu } \\
\text { oleh tim }\end{array}$ \\
\hline Keempat & $\begin{array}{l}\text { Pelayanan } \\
\text { Kesehatan } \\
\text { Pelayanan } \\
\text { kesehatan } \\
\text { diberikan sesuai } \\
\text { dengan } \\
\text { permasalahan } \\
\text { antara lain: } \\
\text { 1. Pemberian } \\
\text { tablet } \\
\text { tambah } \\
\text { darah atau } \\
\text { Vitamin } \\
\text { Merujuk } \\
\text { remaja ke } \\
\text { fasilitas } \\
\text { kesehatan } \\
\text { jika } \\
\text { diperlukan }\end{array}$ & $\begin{array}{l}\text { Kader } \\
\text { dibantu } \\
\text { oleh tim } \\
\text { Dengan } \\
\text { dipantau } \\
\text { oleh } \\
\text { tenaga } \\
\text { kesehatan }\end{array}$ \\
\hline
\end{tabular}

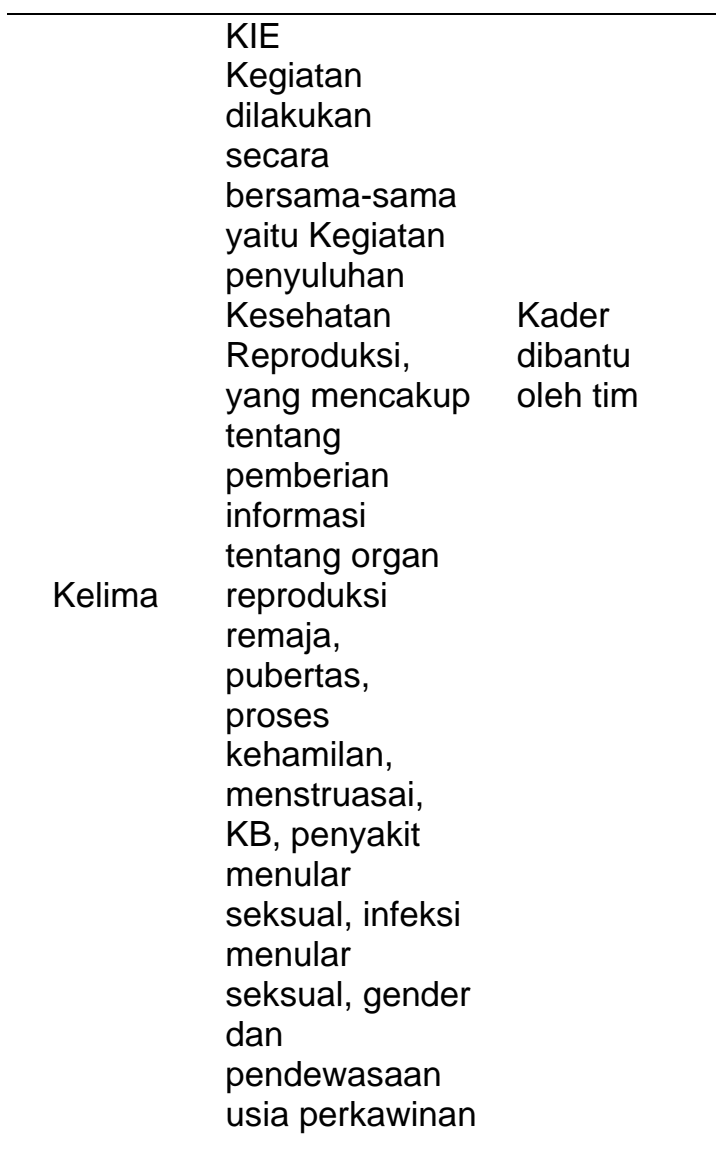

3. Tahap Evaluasi

Setelah kegiatan posyandu remaja selesai, tim posyandu mengadakan pertemuan/ diskusi singkat tentang hasil pelaksanaan posyandu. Semua kader dan pengelola mengemukakan permasalahan dan kendala yang ditemui. Sebagian besar remaja di Dusun 2 Desa Cibiru Wetan kurang pengetahuan dan pemahaman terhadap Kesehatan Reproduksi, hasil dari pemeriksaan serta rencana untuk selanjutnya yang akan dilakukan pada minggu ke-3 setiap bulannya.

Berdasarkan hasil kesepakatan tim pengelola posyandu remaja pelaksanaan posyandu dilaksanakan setiap minggu ke-3, dengan ketentuan bahwa apabila tanggal tersebut bertepatan dengan tanggal merah atau hari libur nasional, dikarenakan mayoritas remaja di dusun II berstatus pelajar.

Secara rutin posyandu dilaksanakan dalam serangkaian proses mulai dari tahap persiapan, tahap pelaksanaan, dan tahap evaluasi. Penyelenggaraan Posyandu Remaja sekurang-kurangnya satu kali dalam sebulan. Jika diperlukan, hari buka Posyandu Remaja dapat lebih dari satu kali dalam sebulan. Hari dan waktunya sesuai dengan hasil kesepakatan .

Posyandu Remaja ini berlokasi di Dusun 
2 Desa Cibiru Wetan Kabupaten Bandung. Kegiatan Posyandu Remaja diselenggarakan di RT 3 RW 06 Cibangkonol di salah satu rumah yang biasa ditempati untuk posyandu.

Pelayanan kesehatan reproduksi sangat dibutuhkan oleh remaja untuk menghindari kehamilan yang tidak diinginkan, aborsi yang tidak aman, penyakit menular seksual dan akibat dari ketidaktahuan remaja tentang informasi kesehatan reproduksi (Kurniawati \& Rohmah, 2019).

Keberadaan posyandu remaja merupakan solusi yang dapat ditawarkan dimasyarakat. Sehingga dengan adanya posyandu remaja di tingkat pedukuhan dapat meningkatkan kesejahteraan serta kesehatan reproduksi remaja.Kegiatan ini menggambarkan hasil pelaksanaan Iptek bagi Masyarakat (IbM) dalam bentuk pelatihan kader untuk pembentukan posyandu remaja. (Putri \& Rosida, 2017).

\section{SIMPULAN DAN SARAN}

Pada kegiatan pengabdian masyarakat ini telah terbentuknya kader kesehatan remaja berjumlah 7 orang yang sudah diberikan pengetahuan mengenai kegiatan posyandu remaja. Serta terlaksananya posyandu remaja dengan lancar dan untuk mendukung keberlanjutan kegiatan, maka para kader remaja inipun menyusun dan membuat program kegiatan selanjutnya. Oleh karena itu kepada pihak terkait dalam hal ini bidan desa, puskesmas dan para aparatur terkait untuk bekerjasama dalam hal memonitoring keberlangusan kegiatan posyandu remaja serta perlu diadakannya program refresing kader kesehatan remaja ini guna untuk terus mengupdate pengetahuan terbaru terutama tentang kesehatan reproduksi remaja

\section{UCAPAN TERIMAKASIH}

Tim mengucapkan terima kasih kepada pihak mitra yang telah bersedia membantu dalam terlaksananya kegiatan pengabdian masyarakat, sehingga tujuan luaran dari kegiatan ini yaitu pemebntukan kader dan posyandu remaja bisa terwujud, serta kami ucapkan terima kasih kepada LPPM Universitas Bhakti Kencana serta Jajaran Dekanat Fakultas IImu Kesehatan yang telah mendukung terlaksananya kegiatan pengabdian masyrakat ini.

\section{DAFTAR RUJUKAN}

Afrita, M., Rahfiludin, M., \& Dharminto, D. (2019). Peran Posyandu Remaja Terhadap Perilaku Kesehatan Reproduksi Remaja Di Kota Tanjungpinang. Jurnal IImu Kesehatan
Ar-Rum Salatiga, 4(1), 17-22.

Izah, N., Zulfiana, E., \& Qudriani, M. (2019). Pembentukan kader KRR pada siswa SMK. E-DIMAS: Jurnal Pengabdian kepada Masyarakat, 10(1), 111-115.

Janah, E., Zakiudin, A., \& Lestari, A. (2019). Pencegahan Hiv/AIDS melalui Penyuluhan Kesehatan Reproduksi dan Pembentukan Kader Kesehatan Remaja. Prosiding Seminar Nasional LPPM UMP 2019, 54-60.

Katan, D., Kholisa, I., \& Sedyowinarso, M. (2014). Pengaruh pelatihan terhadap pengetahuan dan keterampilan kader tentang deteksi dini pendengaran dan penglihatan anak balita di Desa Ambarketawang wilayah puskesmas Gamping 1 Sleman Yogyakarta. Universitas Gadjah Mada.

Kemenkes RI. (2018). Masyarakat dan Kesehatan Keluarga: Petunjuk Teknis Posyandu Remaja. Kementerian Kesehatan RI.

Kemenkes RI. (2019). Pemuda Rumuskan Keterlibatan Bermakna dalam Pembangunan Kesehatan. Kemkes.go.id.

https://www.kemkes.go.id/article/print/ 19032200001/pemuda-rumuskanketerlibatan-bermakna-dalampembangunan-kesehatan.html

Kurniawati, H., \& Rohmah, F. (2019). Pembentukan Kare (Kader Remaja) Peduli HIV dan Aids di Kalintung Temon Kulon Progo. Jurnal Pengabdian Dharma Bakti, 2(1), 66-72.

Margaretha, M. (2012). Psikopatologi dan Perilaku Beresiko Remaja. www.psikologiforensik.com/2012/03/02 /perilaku-beresiko-remaja-seks-adiksidan-hiv/

Nawangsari, E. (2017). Pemerdayaan Remaja Melalui Posyandu Remaja Mandiri di Puskesmas Tambakrejo Simokerto Surabaya. Jurnal Manajemen Jayanegara, 9(1), 55-65.

Puslitbang Kemenkes RI. (2015). Hasil Survey Nasional Kesehatan Berbasis Sekolah Pelajar SMP dan SMA 2015. www.gizi.depkes.go.id/wpcontent/uplo ads/2017/01/GSHS diseminasidiseminasi-agus-Nunik-25-jan-17.pdf

Putri, I., \& Rosida, L. (2017). Pelatihan Kader Pembentukan Posyandu Remaja Di Dusun Ngentak Bangunjiwo Kasihan Bantul Yogyakarta. Prosiding Seminar Nasional Publikasi Hasil-Hasil Penelitian dan Pengabdian Masyarakat, 528-533.

Ruwayda, R., \& Izhar, M. (2020). 
Pemberdayaan Peran Kader Melalui Posyandu Remaja Plus KIE Kesehatan Reproduksi Di Posyandu Remaja Kelurahan Penyengat Rendah Kota Jambi. GEMASSIKA: Jurnal Pengabdian Kepada Masyarakat, 4(2), 165-172.

Saleh, A., \& Kunoli, F. (2018). Pengaruh penyuluhan dan pelatihan melalui media leaflet terhadap pengetahuan kader PHBS di Kecamatan Ratolindo Kabupaten Tojo Una-Una. PROMOTIF: Jurnal Kesehatan Masyarakat, 8(2), 159-164.

Sari, D. (2019). Posyandu Remaja, Solusi Atasi Masalah pada Remaja. Sulawesi Selatan. Kompasiana. www.kompasiana.com/debbywuri/5d6 1c677097f3617793d63d2/posyanduremaja-solusi-atasi-masalah-padaremaja

Sulastri, E., Astuti, D., \& Handayani, E. (2019). Pembentukan Posyandu Remaja Desa Madureso Kecamatan Kuwarasan Kabupaten Kebumen. Proceeding of The 10th University Research Colloquium 2019: Bidang Pengabdian Masyarakat, 130-133.

Wahyuntari, W., \& Ismarwati, I. (2020). Pembentukan kader kesehatan posyandu remaja Bokoharjo Prambanan. Jurnal Inovasi Abdimas Kebidanan (JIAK), 1(1), 14-18.

Zimmer-Gembeck, M. (2002). The development of romantic relationships and adaptations in the system of peer relationships. Journal of Adolescent Health, 31, 216-225. 